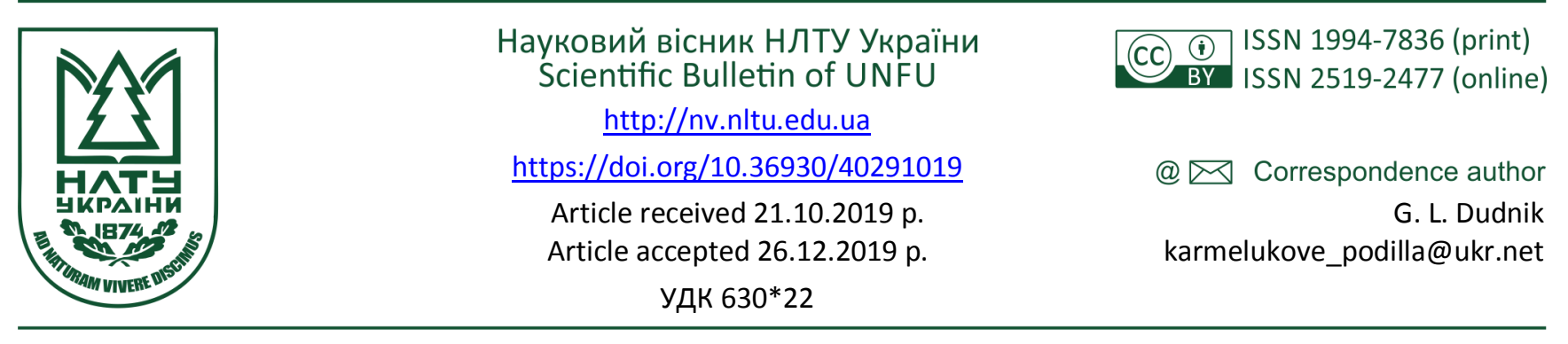

Г. П. Леонтяк1, Г. Л.Дудник ${ }^{2}$

${ }^{1}$ Вінницький національний аграрний університет, м. Вінниця, Україна

${ }^{2}$ Національний природний парк "Кармелюкове Поділля", смт Чечельник, Украӥна

\title{
РОЛЬ НАЦІОНАЛЬНОГО ПРИРОДНОГО ПАРКУ "КАРМЕЛЮКОВЕ ПОДІЛЛЯ" У ЗБЕРЕЖЕННІ ЛІСОВОЇ ЕКОСИСТЕМИ
}

\begin{abstract}
Наведено характеристику лісової екосистеми НПП "Кармелюкове Поділля", яка є переважаючою на природно-заповідній території та має виключне наукове значення як зразок праландшафтів центральної частини України. Цінність природних екосистем Парку полягає в їх незначній порушеності, частково еталонності. У лісах Парку близько 60 \% їх площі займають ліси природного походження. Основною лісовою формацією є дубово-грабові насадження. 3 аналізу матеріалів лісовпорядкування насаджень видно те, що площа лісів природного походження постійно зменшується. Це свідчить про зниження потенційної здатності до самовідновлення цих природних комплексів. Тому для забезпечення збереження і відновлення лісів Парку необхідно розробити і впровадити систему заходів, що враховує природоохоронний режим природо-заповідної території. 3 огляду на те, розглянуто природоохоронний режим території Парку як наслідок іiі диференційованого зонування, що відображає просторову диференціацію функцій, які ця територія має виконувати. Виявлено особливості ведення лісового господарства в умовах природно-заповідного фонду та режим використання природних ресурсів у межах функціональних зон. Узагальнено висновки щодо збереження цінних природних комплексів і біорізноманіття, забезпечення максимально природного перебігу процесів та запровадження екологічно збалансованого природокористування.
\end{abstract}

Ключові слова: природний комплекс; лісовий масив; деревостан; природоохоронний режим; біорізноманіття; раціональне природокористування.

Вступ. Серед усіх типів наземних екосистем найбільш поширеними і найціннішими є ліси. Ліс - це елемент географічного ландшафту, що складається із сукупності деревних, чагарникових, трав'яних рослин, тварин і мікроорганізмів, які у своєму розвитку взаємозв'язані, впливають одне на одного і на навколишнє середовище. Лісова екосистема - це природний або природно-антропогенний лісовий комплекс, що об'єднує угрупування живих організмів і середовища їхнього існування в єдине ціле. Складається 3 абіотичних і біотичних компонентів, які взаємодіють між собою шляхом обміну речовиною, енергією та інформацією в межах однорідної ділянки земної поверхні. Ці взаємозв'язки відбуваються на основі обміну речовин і енергії, без чого неможливе саме існування екосистеми (Dudnyk, 2016; Podillia, 2018, 2016).

Одним із ключових напрямів збереження цінних природних комплексів, рідкісних, реліктових, ендемічних, лісових екосистем є збільшення територій природно-заповідного фонду України. Режим збереження лісових екосистем, порядок їх охорони, ефективного використання та відтворення лісових ресурсів у межах природо-заповідного фонду України є диференційованим залежно від встановлених категорій об'єктів природнозаповідного фонду, а також природно-кліматичних умов та лісорослинного районування (Podillia, 2018, 2016; Hospodarstvo, 2012).

Національний природний парк - одна 3 найвищих категорій природоохоронних територій. Ідея створення національних парків полягає в переході на такий тип природокористування, який найменшим чином шкодитиме природі (Hospodarstvo, 2012; Romanchuk, \& Dudnyk, 2018).

Викладення основного матеріалу дослідження. Національний природний парк "Кармелюкове Поділля" створено згідно з Указом Президента України № 1057/2009 від 16 грудня 2009 р. Перебуває у державній власності та підпорядкований Міністерству екології та природних ресурсів України (Romanchuk, \& Dudnyk, 2018; Chervona knyha Ukrainy, 2009).

Одним з основних завдань Парку є збереження та відтворення цінних природних та історико-культурних комплексів і природних об'єктів лісостепової зони, зокрема штучні лісові масиви та степові ділянки, підтримання та забезпечення екологічної природної рівноваги в регіоні (Cherniavskyi, 2016; Yatsentiuk, 2011).

Парк розташований у південно-східній частині Вінницької обл. в Тростянецькому та Чечельницькому рнах, в адміністративних межах 12 сільських рад. До території Парку погоджено, в установленому порядку,

Інформація про авторів:

Леонтяк Григорій Прокопович, д-р с.-г. наук, професор, академік Лісівничої академії наук України. Email: karmelukove_podilla@ukr.net

Дудник Ганна Леонідівна, головний природознавець. Email: karmelukove_podilla@ukr.net

Цитування за ДСтУ: Леонтяк Г. П., Дудник Г. Л. Роль національного природного парку "Кармелюкове Поділля" у збереженні лісової екосистеми. Науковий вісник НЛтУ України. 2019, т. 29, № 10. С. 93-96.

Citation APA: Leontyak, G. P., \& Dudnik, G. L. (2019). The role of Karmelyuk podillya national nature park in the conservation of the forest ecosystem. Scientific Bulletin of UNFU, 29(10), 93-96. https://doi.org/10.36930/40291019 
включення 20203,4 га земель державної власності, в тому числі 16518 га земель, які вилучаються у державного підприємства "Чечельницький лісгосп" та надаються Парку в постійне користування, і 3685,4 га земель, що включаються до його складу без вилучення у землекористувачів.

Природно-територіальні комплекси Парку мають великомозаїчну структуру, ядром якої є лісові масиви, зосереджені в декількох ізольованих урочищах: "Торканівська дача" (1190 га), "Крамарівська дача" (3686 га), "Бритавська дача" (5365 га), "Червоно-Гребельська дача" (2510 га), "Вербська дача"(1171 га) та інші.

Парк $є$ ключовою територією Чечельницького національно природного ядра в межах регіональної екомережі Вінницької обл. Більша частина ядра (понад 80 \%) знаходиться у межах Чечельницького адміністративного району. Основу природного ядра становлять ботанічні заказники: "Бритавський" (3259 га) та "Червоногреблянський" (1492 га), відповідно загальнодержавного і місцевого значення, а також ботанічний заказник місцевого значення "Вербська дача" (46 га), ботанічні пам'ятками природи загальнодержавного значення "Терещуків яр" (3,8 га) і "Ромашково"(8,7 га).

Тут переважають ландшафти лесових височин, розчленованих врізаними до кристалічних порід ярами i балками, зі сірими і темно-сірими лісовими грунтами, 3 грабовими дібровами, а також ландшафти лесових височин із чорноземами опідзоленими й типовими, з дібровами із дубів звичайного та скельного. Флористичну основу цього природного ядра утворюють типові, рідкісні рослини (Hospodarstvo, 2012; Cherniavskyi, 2016).

Ці ліси відзначаються винятковим багатством дендрофлори. Основною лісовою формацією є дубово-грабові ліси. Вагому наукову і практичну цінність мають скельнодубові насадження. У другому ярусі їх деревостанів трапляється субсередземноморський вид - берека (Sorbus torminalis (L.) Crantz). Такі насадження практично відсутні на територіях заповідних об'єктів України. Особливо цінними є значні площі наближених до корінних насаджень із переважанням у підліску дерену справжнього (Cornus mas L.). У лісових масивах парку виявлено рідкісно рослинні угруповання, занесені до Зеленої книги України - групи асоціацій: дубових лісів із дуба скельного кизилових, дубових лісів з дуба звичайного кизилових, дубових лісів з дуба звичайного татарсько-кленових; асоціації: грабово-дубового лісу із дуба звичайного плющевого та грабово-дубового лісу 3 дуба звичайного маренково-плющевого, грабово-дубового лісу волосистоосокового та грабово-дубового лісу яглицевого, дубового лісу із дуба звичайного свидиново-парвськоосокового, мішаних дубових лісів із дуба звичайного ведмежоцибулевих.

За біогеографічним районуванням України, Парк знаходиться у межах Сіретсько-Середньобузького округу Східно-Субсередземноморської провінції Лісостепової підзони Неморально-лісової зони. Південніше Парку проходить межа між Лісостепом і Степом. Парк відіграє надзвичайно важливу роль як єдиний заповідний в умовах південного заходу Лівобережного Лісостепу, анклав реліктових Кодимо-Савранських лісових ландшафтів, насичених субсередземноморськими елементами флори і фауни.

Згідно 3 геоботанічним районуванням України, територія Парку належить до Південно-подільського ок- ругу дубових лісів та лучних степів Української лісостепової під провінції Східноєвропейської лісостепової провінції дубових лісів, остепнених лук та лучних степів Європейсько-Азіатської степової області (Podillia, 2016; Chervona knyha Ukrainy, 2009).

Ліси та інші вкриті лісом землі на території Парку займають 88,5 \% площі. Згідно з лісорослинним районуванням, вони належать до зони широколистяних мішаних лісів південної частини Лісостепу України.

Частка лісових культур у межах лісових земель становить близько $40 \%$, решта лісів $\epsilon$ дібровами природного походження. Переважають середньовікові (35,2 \%) й стиглі та перестійні $(21,4 \%)$ за лісівничими нормами насадження. Найстаріші ділянки лісу збереглися у південній частині масивів Бритавської і Червоногребельської дач, у межах наявних ботанічних заказників.

Лісова рослинність у Парку представлена переважно дубовими лісами. Деревостани утворюють два види дуба - дуб звичайний (Q. Robur L.) $(88,9$ \%) і дуб скельний (Quercus petraea Liebel.) (0,1 \%). Саме тут проходить північно-східна межа більш теплолюбного, посухостійкого дуба скельного, якого заміщає на північ дуб звичайний (Hospodarstvo, 2012; Cherniavskyi, 2016).

До поширених у цих деревостанах видів також належать ясен звичайний (Fraxinus excelsior L.), граб звичайний (Carpinus betulus L.), клен гостролистий (Acer platanoides L.), клен польовий (Acer campestre L.), липа серцелиста (Tilia cordata L.) та ін. Значну наукову i практичну цінність мають скельнодубові насадження, де у другому ярусі деревостану у великій кількості трапляється субсередземноморський вид, занесений до Червоної книги України - берека (Sorbus torminalis).

Чагарниковий ярус також досить різноманітний, його складають кизил звичайний (Cornus mas L.), клен татарський (Acer tataricum L.), свидина кров'яна (Swida sanguinea L.), гордовина (Viburnum lantana L.) та інші види. Домінантами трав'яного ярусу є переважно осока парвська (Carex brevicollis), зеленчук жовтий (Lamium galeobdolon), зірочник ланцетолистий (Stellaria holostea). У широких плескатих днищах - ценози 3 переважанням кропиви жабрійолистої (Urtica galeopsifolia) та цибулі ведмежої (Allium ursinum), конвалії звичайної (Convallaria majalis), барвінку малого (Vinca minor), плюща звичайного (Hedera helix) та ін.

На узліссях та у прилеглих балках значно поширюються угруповання ксерофітних чагарників 3 домінуванням терену колючого (Prunus spinosa), трапляються герань криваво-червона (Geranium sanguineum), різні види конюшини (найчастіше - конюшини середньої (Trifolium medium) та альпійської (T. alpestre)) та ін.

Територія розміщення Парку належить до Подільського регіону, стан якого визнано екологічно кризовим в Україні. До цього призвели наслідки надзвичайної ситуації природного походження - ліси зазнали масштабних ушкоджень внаслідок ожеледі та льодоламу 2000 р. Стихією було пошкоджено 90,1 \% вкритих лісовою рослинністю земель або 14738 га їх площі. Як результат, масово спостерігали обламування крон дерев, пошкодження та злам стовбурів деревостанів, внаслідок чого відбулось повне або часткове всихання, сповільнення росту та ослаблення насаджень, погіршився загальний санітарний стан лісового фонду. Через появу великої кількості водяних пагонів на стовбурах дерев, погір- 
шився фітопатологічний, ентомологічний стан лісів та знизилась їхня технічна якість.

Для приведення насаджень у належний санітарний стан запроектовано суцільні санітарні рубки на площі 185,0 га, санітарно-вибіркові рубки на площі 3751,5 га. Особливістю природно-заповідної території $є$ ії диференційоване зонування та, відповідно до нього, встановлення природоохоронного режиму. Згідно з Проектом організації території національного природного парку, виділено такі зони: заповідна зона, зона регульованої рекреації, зона стаціонарної рекреації та господарська зона.

Основу заповідної зони Парку складають ботанічний заказник місцевого значення "Червоногребельський" (частково), ботанічний заказник місцевого значення "Вербська дача", ботанічний заказник загальнодержавного значення "Бритавський" (частково), пам'ятка природи загальнодержавного значення "Терещуків яр", пам'ятка природи загальнодержавного значення "Ромашково" (Dudnyk, 2016; Romanchuk, \& Dudnyk, 2018).

Загальна площа заповідної зони становить 3973, 7 га або 19, 66 \% від загальної площі Парку, в тому числі 3961, 2 га земель, наданих Парку в постійне користування. Зона регульованої рекреації в межах Парку включає природні території, що мають рекреаційне, еколого-освітне, культурно-виховне та науково-пізнавальне значення. Цю зону створено також для запобігання негативному впливу природних чи антропогенних чинників на екосистеми заповідної зони.

Загальна площа зони регульованої рекреації становить 7165, 1 га, або 35, 5 \% від загальної площі Парку. Зона стаціонарної рекреації має забезпечити якісний довготривалий відпочинок відвідувачів Парку. У межах цієї зони планується розміщення об'єктів рекреаційної інфраструктури. Переважно це лісові кордони та ділянки під адміністративними та господарськими спорудами. Передбачено, що в цій зоні будуть розміщені капітальні споруди для коротко- та довготермінового відпочинку рекреантів. Загальна площа зони стаціонарної рекреації становить 10,6 га або 0,1 \% від загальної площі Парку (Podillia, 2018, 2016; Hospodarstvo, 2012).

Господарську зону створено насамперед для здійснення господарської діяльності, спрямованої на виконання покладених на Парк завдань, а також 3 метою втілення принципів сталого природокористування 3 якомога найменшим впливом на навколишні природні екосистеми та процеси. Функціональне зонування НПП "Кармелюкове Поділля" є передумовою його подальшого розвитку, збереження біорізноманіття та раціональне природокористування. При цьому необхідне дотримання таких принципів господарювання:

- безперервне існування лісового покриву, який підтримується вибіркою окремих дерев або їхніх біогруп;

- збереження біотичного різноманіття, яке грунтується на постійній підтримці лісу як екосистеми;

- відтворення структури природних різновікових лісів, що має за мету формування породної, просторової і вікової структури, яка близька до пралісової;

- постійне підтримання стійкості деревостанів, яка зумовлюється безперервним існуванням лісового покриву;

- вирубування деревини в обсязі річного приросту, що означає збалансування процесів природного наростання фітомаси і вибирання іiі у процесі заготівлі деревини приблизно на одному рівні;
- постійна стабільність природоохоронних, захисних, кліматорегулювальних, санітарно-гігієнічних, оздоровчих та інших корисних властивостей лісів;

- збереження грунтового покриву - необхідна умова постійного існування та повноцінного функціонування всіх живих компонентів лісу;

- природоохоронні технології заготівлі деревини, які зумовлюються зведенням до мінімуму негативного впливу на лісове середовища.

Висновки. Особливістю ведення лісового господарства в умовах природно-заповідного фонду є збереження цінних природних комплексів і біорізноманіття, забезпечення максимально природного перебігу процесів та запровадження екологічно збалансованого природокористування. Це $\epsilon$ передумовою розроблення системи заходів щодо відновлення природного стану лісів, порушеного внаслідок господарської діяльності людини, а саме максимального стимулювання появи насіннєвого поновлення дуба, буде сприяти його росту і розвитку, переформування дібров паростевого походження у насіннєві, створення мішаних за складом і складних за структурою насаджень.

Згідно з Літописом природи, представниками рослинного світу, які занесено до Червоної книги України, є 29 видів, серед яких: берека (Sorbus torminalis L.), цибуля ведмежа (Allium ursinum L.), осока затінкова (релікт) (Carex umbrosa Host), шафран сітчастий (Crocus reticulatus), бруслина карлікова (релікт) (Euonymus na$n a)$, підсніжник звичайний (Galanthus nivalis L.), лілія лісова (Lilium martagon L.), скополія карніолійська (Scopolia carniolica) та інші.

Список тварин, занесених до Червоної книги України, нараховує 20 видів. Під час виконання лісогосподарських робіт потрібно особливо охороняти та захищати рідкісні лісові рослинні угрупування: формація звичайнодубових лісів ведмежоцибулевих; формація звичайнодубових лісів дернових; формація звичайнодубових лісів свидинових; формація скельнодубово-звичайнодубових лісів; формація скельнодубових лісів свидинових.

Парк уособлює природу Південного Поділля, регіону, в яких типові подільські елементи і рослині комплекси вбирають у себе з одного боку значну кількість південних субсередземноморських елементів, а 3 іншого - деякі південно-східні елементи, які тут перебувають на західній межі поширення. Важливою є созологічна значущість і цінність природних комплексів Парку. Особливістю, яка притаманна саме "Кармелюковому Поділлю", $є$ значна участь лісів природного походження, рідкісних для України, зокрема пристигаючих та стиглих, та багатство біорізноманіття Парку загалом.

Для забезпечення збереження і відновлення лісів Парку необхідним $є$ розроблення і впровадження системи заходів, що охоплює постійні обстеження лісових масивів (зокрема лісопатологічні), моніторинг за їхнім станом, виконання лісовідновлювальних робіт та, в разі необхідності, вживання санітарно-оздоровчих заходів, доглядових рубань тощо.

\section{References}

Cherniavskyi, M. V. (2016). Pryrodno blyzke lisivnytstvo v dibrovakh Podillia. Zberezhennia rarytetnoho bioriznomanittia $\mathrm{v}$ natsionalnykh pryrodnykh parkakh. Zberezhennia rarytetnoho bioriznomanittia $v$ natsionalnykh pryrodnykh parkakh: Materials of the scientific and practical seminar of employees of institutions of the na- 
tural reserve fund, NPP "Karmeliukove Podillia", (pp. 71-80), July 26-27. Vinnytsia: FOP Korzun D. Yu. [In Ukrainian].

Chervona knyha Ukrainy. (2009). In Ya. P. Didukh (Ed.), Roslynnyi svit. Kyiv: Hlobalkonsaltynh, 900 p. [In Ukrainian].

Dudnyk, H. L. (2016). Vplyv pryrodokorystuvannia na zberezhennia bioriznomanittia v NPP "Karmeliukove Podillia". Zberezhennia rarytetnoho bioriznomanittia $v$ natsionalnykh pryrodnykh parkakh: Materials of the scientific and practical seminar of employees of institutions of the natural reserve fund, (pp. 10-12). NPP "Karmeliukove Podillia", July 26-27. Vinnytsia: FOP Korzun D.Yu. [In Ukrainian].

Hospodarstvo. (2012). Proekt lisovporiadkuvannia DP "Chechelnytske lisove hospodarstvo". Irpin, 150 p. [In Ukrainian].

Podillia. (2016). Proekt orhanizatsii terytorii natsionalnoho pryrodnoho parku "Karmeliukove Podillia", okhorony, vidtvorennia ta rekre- atsiinoho vykorystannia yoho pryrodnykh kompleksiv i obiektiv, (Vol. 2). Kyiv: PrAT "naukovo-vyrobnychyi kompleks "Kurs"; PP "Tsentr ekolohichnoho upravlinnia", 103 p. [In Ukrainian].

Podillia. (2018). Litopys pryrody NPP "Karmeliukove Podillia", (Vol. 5). Vinnytsia: FOP Prysiazhniuk V. V., 303 p. [In Ukrainian].

Romanchuk, O. P., \& Dudnyk, H. L. (2018). Rol NPP "Karmeliukove Podillia" u formuvanni ekomerezhi Vinnytskoi oblasti. Dosvid ta perspektyvy zberezhennia pryrodo-zapovidnoho fondu Khmelnychchyny: Collection of materials of the All-Ukrainian scientificpractical conference with international participation, (pp. 50-55). Slavuta: TOV "Kalihraf". [In Ukrainian].

Yatsentiuk, Yu. V. (2011). Ekomerezha Vinnytskoi oblasti. Vinnytsia: PP "TD "Edelveis i K", 128 p. [In Ukrainian].

G. P. Leontyak1, G. L. Dudnik

${ }^{1}$ Vinnytsia National Agrarian University, Vinnytsia, Ukraine ${ }^{2}$ National Park "Karmelyukove Podillya", Chechelnik, Ukraine

\section{THE ROLE OF KARMELYUK PODILLYA NATIONAL NATURE PARK IN THE CONSERVATION OF THE FOREST ECOSYSTEM}

The characteristic of the forest ecosystem of the Karmelyuk Podillya National Nature Park, which is predominant in the nature reserve area, is of exceptional scientific significance as an example of the forestscapes of the central part of Ukraine. The value of the natural ecosystems of the Park lies in their negligible disturbance, partly the reference. In the forests of the Park about 60 percent of their area is occupied by forests of natural origin. The main forest formations are oak-hornbeam plantations. The analysis of materials for forest management of plantations indicates that the area of forests of natural origin is constantly decreasing. This indicates a decrease in the potential for self-healing of these natural complexes. Therefore, in order to ensure the preservation and restoration of the forests, the Park needs to develop and implement a system of measures concerning the nature protection regime of the nature reserve area. In this regard, the nature protection regime of the Park territory as a result of its differentiated zoning should reflect the spatial differentiation of the functions that this territory must perform. The features of forest management in the conditions of the nature reserve fund and the mode of using natural resources within the functional zones are revealed. The conclusions are summarized on the preservation of valuable natural systems and biodiversity, ensuring the maximum natural flow of processes and the introduction of ecologically balanced nature management.

Keywords: natural complex; forest massif; forest stand; environmental regime; biodiversity; rational nature management. 